\title{
Correction to: Combination therapy of PKC and COX-2 inhibitors synergistically suppress melanoma metastasis
}

Ping Zhou', Jiaqi Qin ${ }^{\dagger}$, Yuan Li, Guoxia Li, Yinsong Wang, Ning Zhang, Peng Chen ${ }^{*}$ and Chunyu Li ${ }^{*}$

Correction to: J Exp Clin Cancer Res 36, 115 (2017)

https://doi.org/10.1186/s13046-017-0585-2

Following publication of the original article [1], the authors identified some minor errors in imagetypesetting in Figs. 2 and 3; specifically in Fig. 2b, and Fig. 3a and $d$.

In Fig. $2 \mathrm{~b}$, the picture of cell invasion assay in J-4 group has been corrected.

In Fig. 3a, the picture of wound healing assay in J-4 group $(24 \mathrm{~h})$ has been corrected.

In Fig. 3d, the pictures of wound healing assay in Celecoxib group $(0 \mathrm{~h})$ has been corrected.

The corrected figures are given below. The corrections do not have any effect on the final conclusions of the paper.

Published online: 01 March 2021

\section{Reference}

1. Zhou P, Qin J, Li Y, et al. Combination therapy of PKC and COX-2 inhibitors synergistically suppress melanoma metastasis. J Exp Clin Cancer Res. 2017; 36:115. https://doi.org/10.1186/s13046-017-0585-2.

*Correspondence: chenpengdoc@sina.com; lichunyu@tmu.edu.cn

${ }^{\dagger}$ Ping Zhou and Jiaqi Qin contributed equally to this work.

Department of Thoracic Medical Oncology, Tianjin Medical University Cancer Institute and Hospital, School of Basic Medical Sciences, International Medical School, School of Pharmacy, Tianjin Medical University, No. 22 Qixiangtai

Road, Heping District, Tianjin 300070, People's Republic of China

(c) The Author(s). 2021 Open Access This article is licensed under a Creative Commons Attribution 4.0 International License, which permits use, sharing, adaptation, distribution and reproduction in any medium or format, as long as you give appropriate credit to the original author(s) and the source, provide a link to the Creative Commons licence, and indicate if changes were made. The images or other third party material in this article are included in the article's Creative Commons licence, unless indicated otherwise in a credit line to the material. If material is not included in the article's Creative Commons licence and your intended use is not permitted by statutory regulation or exceeds the permitted use, you will need to obtain permission directly from the copyright holder. To view a copy of this licence, visit http://creativecommons.org/licenses/by/4.0/ The Creative Commons Public Domain Dedication waiver (http://creativecommons.org/publicdomain/zero/1.0/) applies to the data made available in this article, unless otherwise stated in a credit line to the data. 

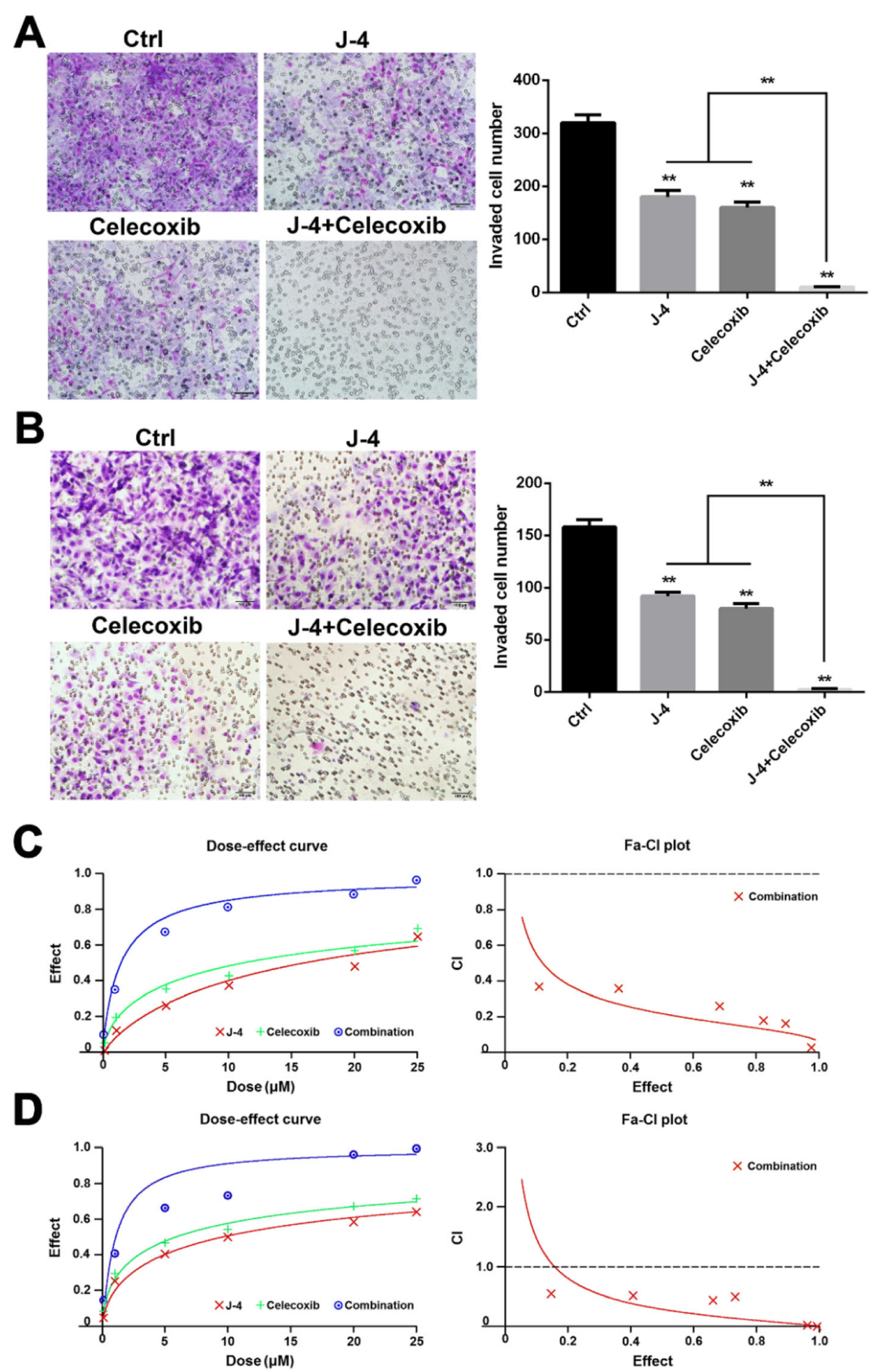

Fig. 2 Combined treatment of J-4 and Celecoxib synergistically inhibited the invasion of melanoma cells. $\mathbf{a}$ and $\mathbf{b}$ The invasion of B16-F10 (a) and A375 (b) cells was significantly inhibited by a 24-h treatment of the combination of J-4 (25 $\mu \mathrm{M})$ and Celecoxib $(25 \mu \mathrm{M})$ assessed via Transwell assay. $\mathbf{c}$ and $\mathbf{d}$ The dose-effect curve and $\mathrm{Cl}$ of the synergistic effect of J-4 with Celecoxib in A375 (c) and B16-F10 (d) cells calculated by the CalcuSyn software 2.1. * $P<0.05 ;{ }^{* *} P<0.0$ 


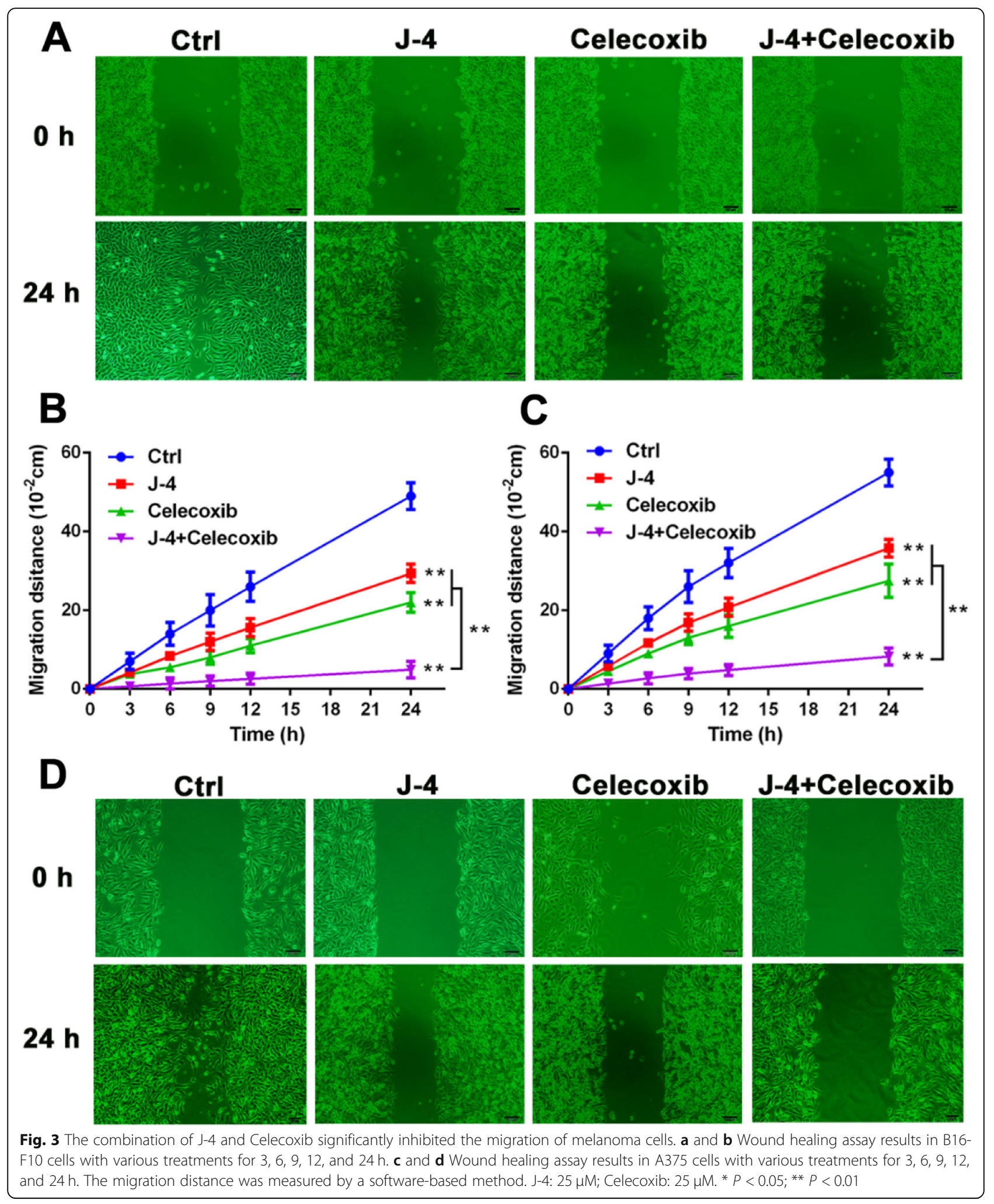

